
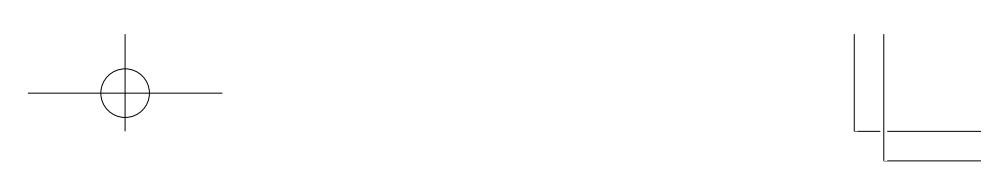

Japanese Research in Business History 2011 | 28

\title{
Pre-war Shipping Markets and Trading Companies
}

\author{
Hisayuki Ōshima
}

\section{Introduction}

$\mathrm{T}$ HIS ESSAY examines trends within the global shipping markets during the period stretching from the 1900s through the 1930s by relating them to developments in the transport trade that addressed the need on the part of trading companies for transport of their goods. In doing so, the essay reveals the formation of an efficient system of transport trade between the trading companies, who owned the goods, and the shipping industry - a system that enabled large Japanese trading companies, as exemplified by the "general trading companies" or sōgōshōsha, to maintain a high level of competitiveness in international trade. Specifically, I will examine the process by which an international shipping market emerged in the port city of Kobe during the latter half of the 1910s, after which the fixed business relationships between trading and shipping companies increased in importance even as the market system declined after the 1920s.

In general, shipping markets have been categorized into liner markets, tramper markets, and special shipping markets, depending on the quality of and demand for transport service as well as differences in the competitive relationships between companies. ${ }^{1}$ By including the

1. Tomohei Chida, Kaiun shijōron [On shipping markets] (Tokyo: Yūhikaku Publishing Co., Ltd, 1958), 6-38.
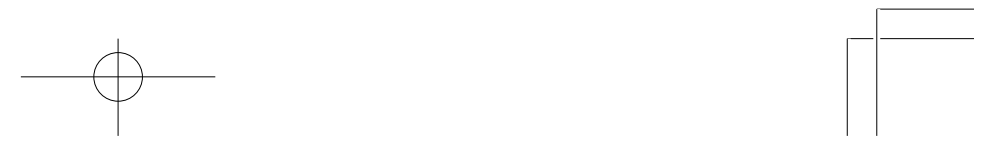

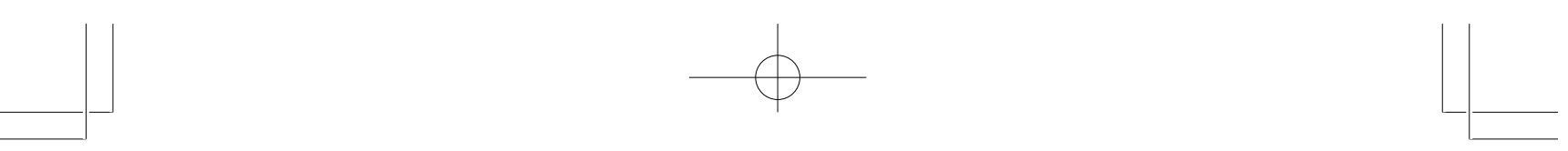

analysis of the relationships between these markets, this essay characterizes the shipping market as the place in which exchanges of the supply and demand of shipping labour (liner labour, tramper labour) take place and freights are determined.

The Baltic Mercantile and Shipping Exchange in London, which has been the centre of the global shipping industry since the nineteenth century, is an example of a market serving as a site in which such supply and demand are coordinated. R. H. Thornton introduces the function of the Baltic Exchange as follows:

A merchant, living perhaps in Copenhagen, telegraphs to his London broker that he wants a ship for 6500 tons of rice, "first half January loading" at Saigon. Within five minutes his broker is on the floor of the "Baltic" and in conversation with a fellowmember, who has a Norwegian ship in hand, at present bound with coal from Durban to Singapore and therefore nicely placed to meet his requirements. After a little haggling, within the limits of say a shilling a ton, the rate of freight is fixed and the business is done. Oslo is no distance from Copenhagen, yet it has been simpler and quicker for the Danish merchant and the Norwegian shipowner to meet, in effect, on the floor of the "Baltic" in London. $^{2}$

In fact, a move within Japan attempted to establish an entity that performed functions similar to the Baltic Exchange. This was the Kobe Shipping Exchange, which was first envisioned when Kawamura Teijirō, who led the shipping department of Mitsui Bussan (Mitsui \& Co., Ltd.), a leading operator of trampers, visited the Baltic Exchange in 1911. This was followed by a decade-long effort to create the exchange, which was officially established in 1921. Ultimately, however, the Kobe Exchange attracted few participants and could not function as a fullfledged market, despite the hopes of its proponents. ${ }^{3}$

Nevertheless, this essay reveals that an international shipping market, which functioned as a global site for coordinating trade, did, in fact,

2. R. H. Thornton, British Shipping (Cambridge: Cambridge University Press, 1939), 139-140.

3. Nihon kaiun shükaijo nijūnenshi [Twenty-year history of the Japan Shipping Exchange] (1941), 53; Nihon kaiun shükaijo sōritsu gojūnenshi shoshi [A short history on the 50th anniversary of the opening of the Japan Shipping Exchange] (1972), 16-17. 


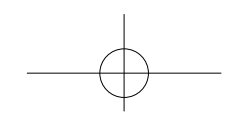

emerge over the course of the 1910s, and that the changes in the nature of trade led to the declining significance of this market during the 1920s. I will also examine how the users, that is, the owners of goods, secured efficient methods of transportation during the time when the market was not fully established.

This essay will also look at the competitiveness of Japanese trading and shipping companies within the international market. In a recent work on British trading companies, Geoffrey Jones analyses how British companies' competitiveness declined greatly during the interwar period-this is in contrast to Japanese companies, which increased their competitiveness by establishing global sales networks during the same period. ${ }^{4}$

At the same time, another work has revealed how the British shipping industry's share of global shipping tonnage also decreased, from the pre-First World War level of at least $40 \%$ to $26 \%$ in 1939, in the face of growing Japanese competition in the vast waters "east of Suez and west of Panama." In response to a request by the British government, the (British) Imperial Shipping Committee investigated the influence of changes in shipping in the Middle and Far East as well as the growing competitiveness of foreign shippers. In late 1938, the committee published its report, British Shipping in the Orient, which pointed to the decreasing value of the yen, the low cost of Japanese crews, government subsidies, and the backing of the shipping industry by the zaibatsu or "financial cliques" as some of the key factors behind the competitiveness of the Japanese shipping industry. ${ }^{6}$ In response to these arguments, this essay points out how changes in the system of

4. Geoffrey Jones, Merchants to Multinationals: British Trading Companies in the Ninetieth and Twentieth Centuries (Oxford: Oxford University Press, 2000), 88-114.

5. S. G. Sturmey, British Shipping and World Competition (London: Athlone Press, 1962), 61-97.

6. Imperial Shipping Committee, British Shipping in the Orient (1938) (Osaka Shōsen, trans., Tōyō ni okeru Eikoku kaiun [British shipping in the orient] (1939), 123129); on the other hand, Keiichirō Nakagawa denies the significance of such factors instead attributing the growth of the Japanese shipping industry during this period to organised entrepreneurial activities (Keiichirō Nakagawa, Ryō-taisenkan no nihon kaiungyō-sono keieishiteki kōsatsu [Japanese shipping industry in the interwar periodits analysis from the perspective of business history] [Tokyo: Chuo University Press, 1985], 1-26).
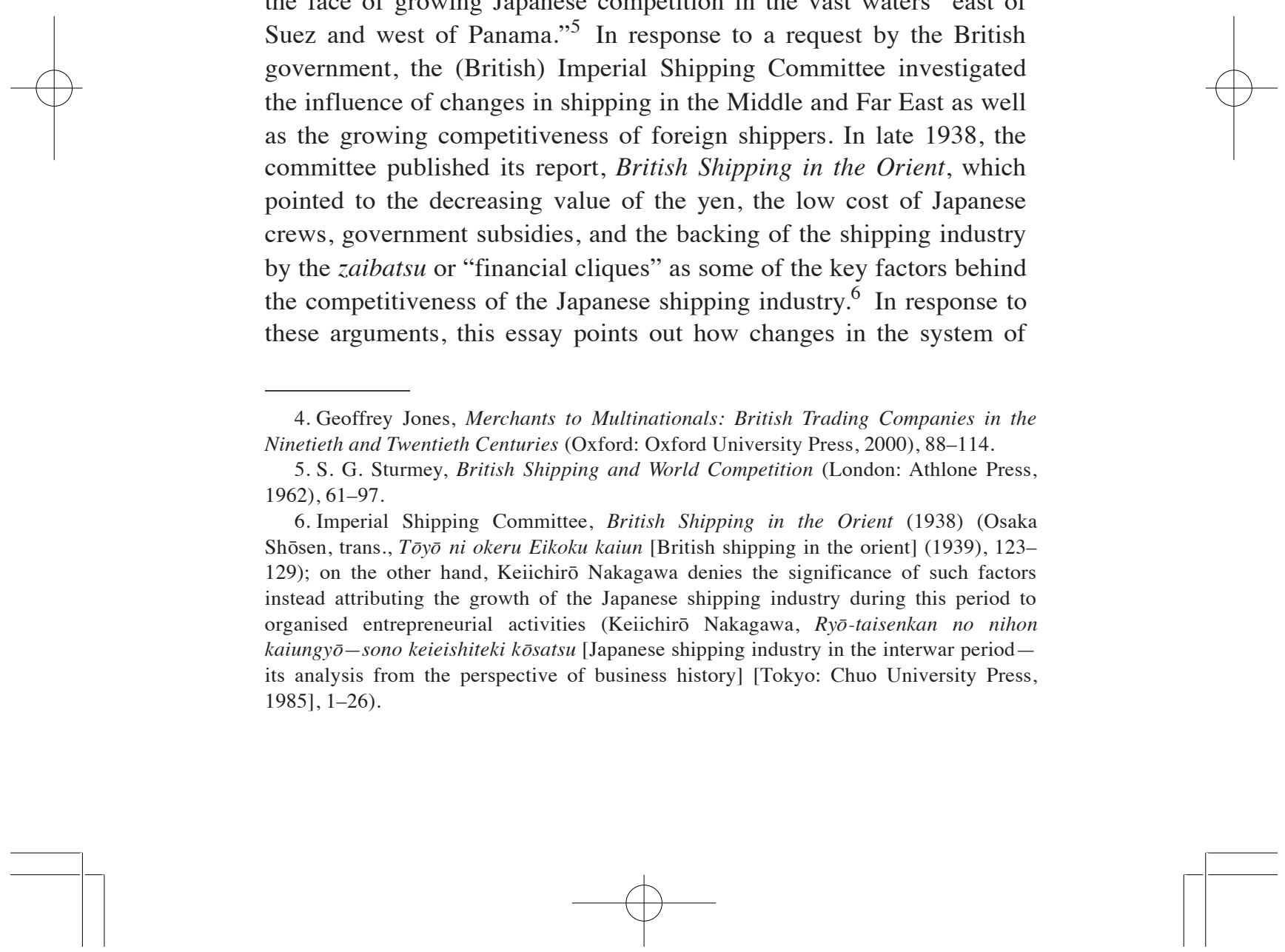
trade within the Japanese shipping market enabled major owners of goods like trading and shipping companies to gain competitiveness in the international market by forming long-term, permanent business relationships with one another. As Geoffrey Jones points out, long-term relationships between trading and shipping companies were also important in Britain but were less fixed and more flexible than they were in Japan, in which agents were changed depending on conditions. In short, this essay seeks to point out the ways in which differences between the Japanese and British systems of shipping trade contributed to the relative competitiveness of these industries in the two nations. ${ }^{7}$

\section{Organized Response Before the Formation of the Market: Before the First World War}

In order to examine the establishment of the Kobe shipping market, this section highlights the organized response among major parties involved with the shipping trade to the growing need for an entity to coordinate trade during the late stages of the Russo-Japanese War. It will do this by examining the case of Mitsui Bussan and the sales department of Mitsubishi Gōshi-Kaisha (Mitsubishi GSK) as examples of major clients who needed to establish efficient methods of transport.

\section{The case of Mitsui Bussan ${ }^{8}$}

For companies that conducted trade between distant locations, the ability to secure an efficient method of transportation and thereby reduce transportation costs was becoming an important determiner of their competitiveness, making it a managerial priority along with the expansion of trading activities. In the case of Mitsui Bussan, then Japan's leading trading company, such need was already being articulated in company meetings by the end of the 1890s. In a meeting in 1898 , for example, board member Ueda urged the company to streamline the inefficient process of hiring ships to secure cargo space,

7. Jones, 245.

8. On Mitsui Bussan during this period, see Hisayuki Ōshima, "Mitsui Bussan ni okeru yusō gyōmu to yōsen shijō“ [Mitsui Bussan's transport business and the chartering market], in Satoshi Nakanishi and Naofumi Nakamura, eds, "Shōhin ryūtsū no kindaishi [A modern history of commodity circulation] (Tokyo: Nihon Keizai Hyōronsha, 2003). 
which was, at the time, conducted across a wide area, leading to overlaps in hiring. ${ }^{9}$ According to Kashiwadani Makoto, Mitsui developed its knowhow in chartering operations in the 1880s at its London branch, where the company worked through the Baltic Exchange to transport rice. Such knowledge was, at that time, limited to only a handful of Japanese companies. ${ }^{10}$

By the 1900s, however, efforts to charter ships within Asia became increasingly important. In the case of coal shipping, it is apparent that Mitsui was expanding its chartering operations from London, where the Baltic Exchange was located, to Asia. ${ }^{11}$ As a result, the company was receiving reports from far-flung branches that, because each branch conducted chartering operations on its own, they were facing situations in which a branch would charter a ship and send it off with cargo, even if another, empty ship that was also chartered by the company was entering the same port on the same day. Without an established shipping market, it was difficult to coordinate even the small-scale demand within the company, which would have been sufficiently met by roundtrip cargo on one ship.

As a form of an organized response to such predicaments, Mitsui created a shipping department to coordinate the transportation of goods in 1903. At a time when there was no established shipping market, Mitsui needed the department in order to centralize the management of shipping within the company and efficiently secure cargo space, as the company's demand for cargo space grew in proportion to its business operations between distant locations.

In addition, the increasing number of ships that were being imported into Japan created the possibility of chartering ships within Japan instead of doing so at locations like Shanghai or Hong Kong, enabling Mitsui to efficiently secure transportation as it alternated between

9. A statement made in an 1898 meeting of the Coal Commerce Advisory Meeting. Discussions in this section on the realities inside Mitsui Bussan are based on internal documents owned by the Mitsui Bunko (Mitsui Archives).

10. Makoto Kasuya, Gōshō no meiji [Meiji of the wealthy merchants] (Aichi: The University of Nagoya Press, 2002), 127-141.

11. Ships chartered in the last half of 1902 by the Moji branch, which was he center of coal trade, included 11 from London, 18 from Hong Kong, 28 from Moji, 13. from Shanghai, one from Singapore, seven from Tokyo, and one from Nagasaki, demonstrating the rise of ship charters in East Asia.
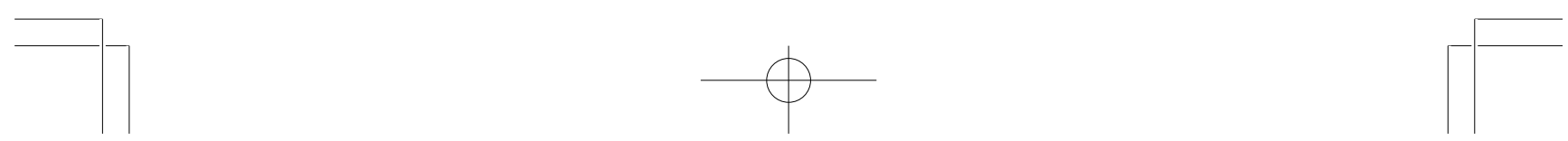
Japanese and foreign ships.

The coordination of supply of and demand for transport through the internal organisations of Mitsui, which boasted unmatched status as a trading company in Japan, served as an important system that replicated the functions of the market in the shipping scene in around 1910. In fact, among the operators of trampers in around 1910, Mitsui found itself in an unparalleled position in the market for chartered ships, as shown in Table 1; it had secured $30 \%$ of the market and was seen to be a 'decisive force that dominated the post-Russo-Japanese War shipping world, as it chartered Japanese ships for long-distance sea lanes in operations like the import of wheat and flour, export of Manchurian soy beans, and the transport of exported coal. ${ }^{12}$

However, coordination by an internal organisation of a major corporation did not necessarily favour other participants in the market. In particular, shipowners outside the company found themselves at a disadvantage when there was no established system to coordinate between markets, such coordination being conducted by a specific company instead. As noted later in this essay, these shipping problems were resolved during the First World War, when a shipping market was formed around the city of Kobe.

\section{The Case of Mitsubishi GSK}

Coordination through an international organisation was one solution to the challenge of coordinating the trade of a diverse range of goods between distant areas, as Mitsui experienced before the First World War. However, there was another solution for companies that sought to deal with imbalance in trade involving specific products and limited areas. Mitsubishi, another major corporation, focused on selling coal during the Meiji period (1868-1912). At the same time, Mitsubishi conducted a long-term contract with the Yahata Steelworks in 1899, which stipulated that the former would transport iron ore from the Daye mine in China to Yahata for ten years. In the same year, Mitsubishi added shipping to the business description in the company statutes, allowing the company to greatly increase its transport capacity before the First World War. The

12. Shizuo Segawa, Kaiun kōkokushi [History of the rise of a shipping nation] (Osaka: Kaiji Ihōsha, 1927), 741.
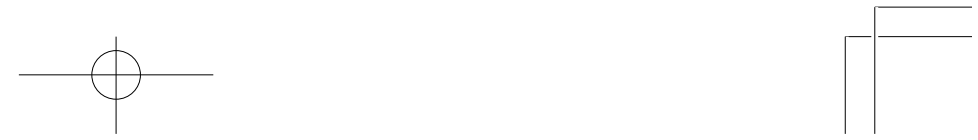


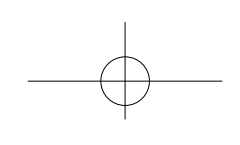

Table 1: Chartered Liners in May 1912

\begin{tabular}{|l|r|r|r|}
\hline \multicolumn{1}{|c|}{ Characterer } & Ship Numbers & Tonnage & Component Ratio \\
\hline Mitsui Bussan & 26 & 88,217 & 29.8 \\
Other domestic shippers & 31 & 67,263 & 22.7 \\
Ōsaka Shōsen (OSK Line) & 9 & 32,672 & 11.0 \\
Nippon Yūsen (NYK Line) & 9 & 30,956 & 10.5 \\
Ministry of Army & 4 & 12,237 & 4.1 \\
Ministry of Railroad & 3 & 4,405 & 1.5 \\
Mitsubishi & 2 & 3,983 & 1.3 \\
Chinese & 12 & 25,365 & 8.6 \\
Western & 10 & 30,875 & 10.4 \\
\hline \hline Total & 106 & 295,973 & 100.0 \\
\hline
\end{tabular}

Note: created from Kobe kaiun gojūnenshi [Fifty year history of the shipping industry in Kobe], 206.

contract with Yahata was not necessarily favourable to Mitsubishi, in that it fixed the freight rate for a long period of time (depending on the size of the transport). Given this, why did Mitsubishi enter into such a contract? In his letter to Director General Nakamura of Yahata, Iwasaki Hisaya, the head of Mitsubishi, explained that, while it was possible to greatly decrease the freight rate by combining the transport of iron ore and coal, an imbalance in the price of coal would exacerbate competition with other companies, making some consideration necessary. ${ }^{13}$ The long-term contract to transport Daye ores, then, came about in part for the purpose of solving the imbalance between Mitsubishi's coal exports and the goods that were transported with them. In the absence of a shipping exchange, this also served the important function of lowering the cost of transporting coal, a commodity that was typically shipped by tramper. Thus, Mitsubishi's contract with Yahata can be understood as a different form of organized response than that which Mitsui pursued.

13. On the transportation of Daye ores by Mitsubishi GSK, see Hisayuki Ōshima, "Kan'ei yahata seitetsujo ni okeru kōseki yusō" [Iron ore transportation in the state-run Yahata Steelworks], Enerugīshi kenkyū, 19 (2004): 29-45. 

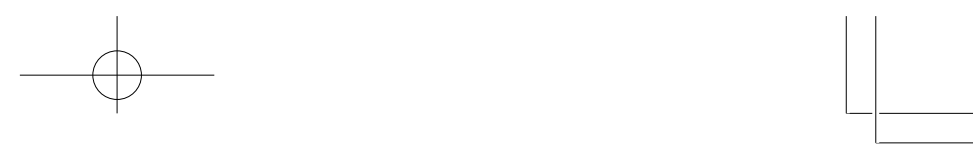

\section{The Formation of an International Shipping Market: the First World War ${ }^{14}$}

As noted in the introduction, the shipping exchange as a public institution ultimately did not develop in Japan, due to the failure of the Kobe Shipping Exchange. In reality, however, Kobe had come to possess the status of a shipping market of global stature in the Far East by the late 1910s. This section will examine how a system that brought the owners of goods and shippers together emerged in Kobe.

During the First World War, an unprecedented boom in shipping transformed the circumstances surrounding the Japanese shipping industry. First, let us examine the shipowners of the so-called shagaisen (non-company ships), whose condition greatly influenced developments in tramper shipping. ${ }^{15}$ The power of shagaisen owners grew rapidly after 1915, when the shipping boom came into full swing. By 1919, these shipowners accounted for 144 tons or $68 \%$ of all steamships. However, most of this rapidly increasing number of shagaisen owners focused on hiring out their ships, which they could not operate themselves. The emergence of a large number of these shipowners in the market is one of the characteristics of this period. Table 2 illustrates this development:

As the table shows, only a quarter of the growing number of shagaisen were operated by the owners themselves, while more than $70 \%$ of the ships were chartered by other operators. Not only that, during this period, we can also see the rise of Japanese shipping companies who chartered the cargo space of ships of this sort owned by charter-oriented shipowners. In other words, the number of ships leased to Japanese charterers began to overtake that hired out to foreign charterers in this period, which counted for $20 \%$ of all shagaisen in 1916. By 1919, Japanese charterers counted for $80 \%$ of all shagaisen.

14. On the chartering markets during the First World War, see Hisayuki Ōshima, "Dai ichiji taisenki ni okeru yōsen shijō" [Chartering markets during the First World War], Takachiho ronsō, 35.4 (2001): 42-78.

15. By this period, ships belonging to the two major shipping companies, Nippon Yūsen (NYK Line) and Osaka Shōsen (OSK Line), were referred to as shasen ("company ships"), while those belonging to their smaller competitors were called shagaisen. 

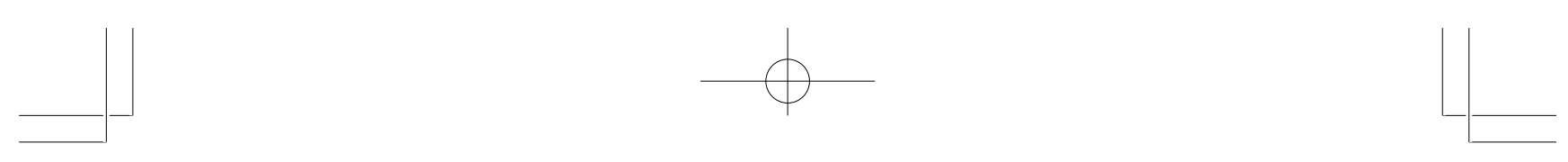

Ōshima: Pre-war Shipping Markets and Trading Companies 93

\begin{tabular}{|c|c|c|c|}
\hline 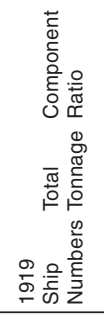 & 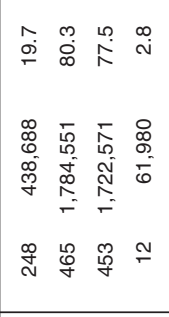 & 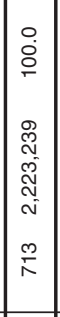 & 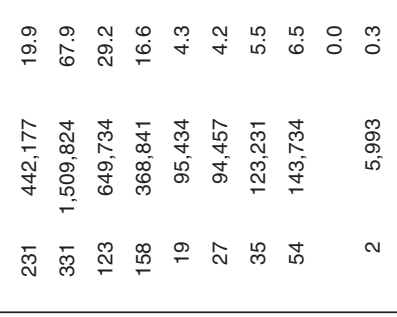 \\
\hline 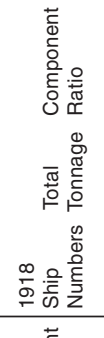 & 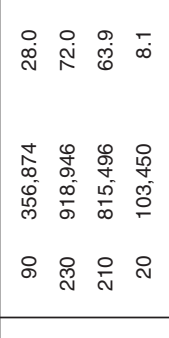 & 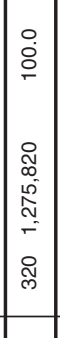 & 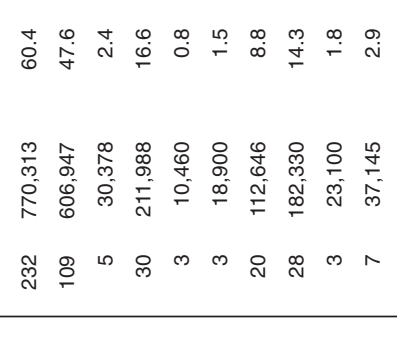 \\
\hline 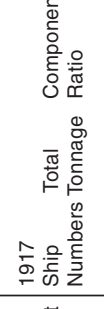 & 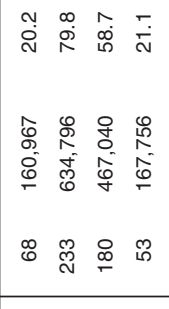 & 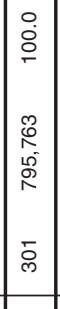 & 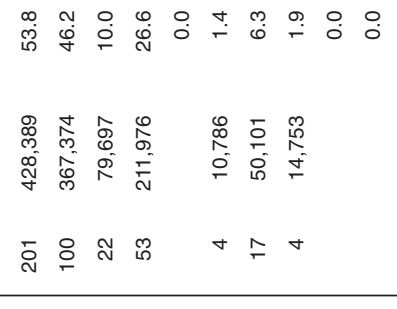 \\
\hline 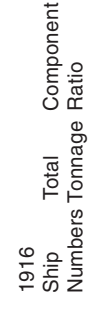 & 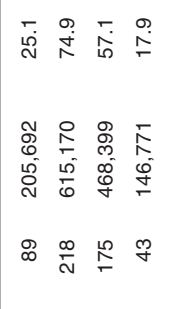 & 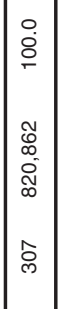 & 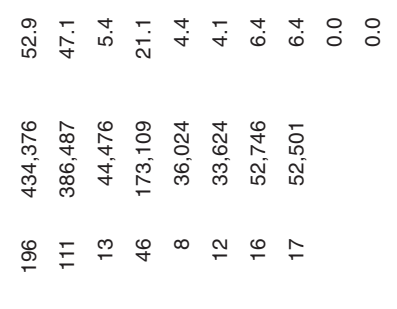 \\
\hline & 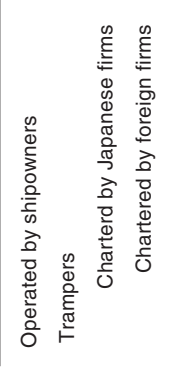 & \begin{tabular}{|l|}
$\frac{\pi}{0}$ \\
$\frac{0}{\circ}$
\end{tabular} & 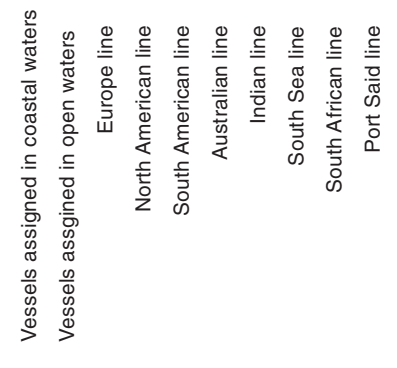 \\
\hline
\end{tabular}
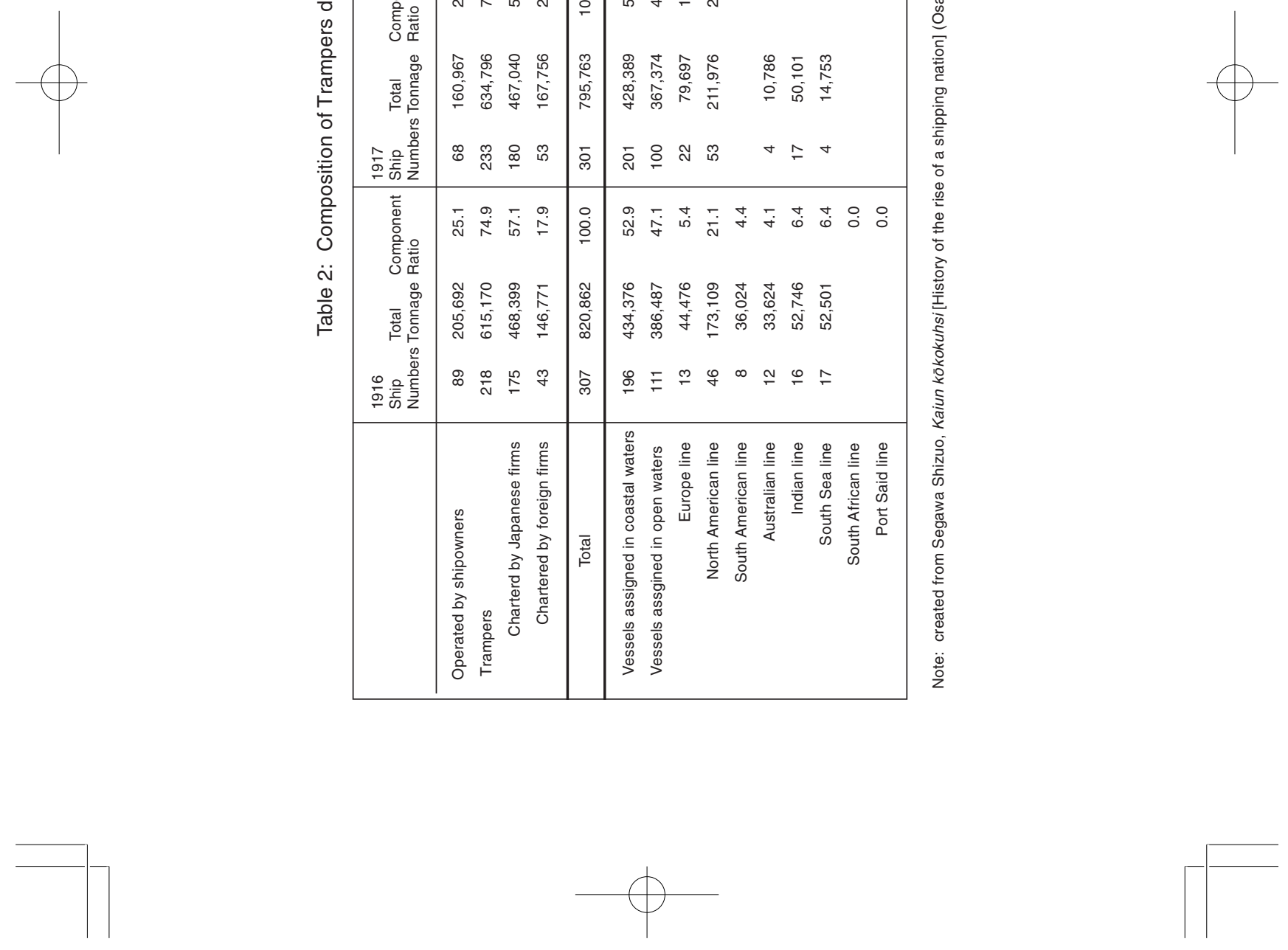

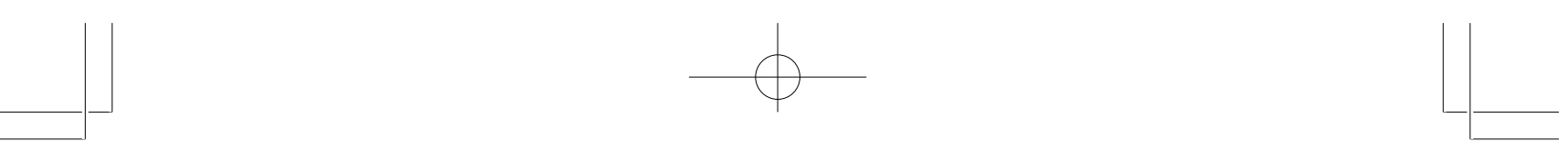

Table 2 also indicates the noteworthy rise in the importance of vessel assignments in the open sea. If one is to summarise the chartering market during the First World War from the points just outlined, the following conclusions can be drawn: first, this period witnessed the emergence of many shagaisen owners and, in particular, of a large number of who did not operate the ships themselves. Second, the same period also saw the rise of shipping companies that chartered cargo space belonging to charter-oriented shipowners for vessel assignments in the open sea. In other words, a national shipping market that brought the numerous charter-oriented shipowners and the Japanese shipping companies together was established during this period.

Because of the increase in the size of the market as a whole, the relative importance of Mitsui Bussan as a major charterer decreased even as the number of ships chartered by the company increased. At the same time, trading companies like Suzuki, Inc. and major operators with global networks, as exemplified by Yamashita Steamship Co., emerged as major charterers, diversifying the identity of the chartering firms within the market. In other words, the mechanism of exchange between the owners of goods and Japanese shipowners, which had been coordinated internally within Mitsui at the end of the Meiji period, increasingly became generalised with the expansion of the domestic shipping market, the diversification of chartering companies, and the existence of intermediaries that brought them together. The entrance of numerous operators with global networks into the market signified a great decline in the significance of coordination within a particular organisation like Mitsui. It is reasonable to think that the participation of major chartering companies like Suzuki, Inc. and Yamashita Steamship had the effect of shrinking the information gap between the Japanese international shipping market and the international market.

Also of great importance in coordinating the shipping trade were the intermediary companies that emerged during this period. These companies were brokers who mediated the dealings between the buyers and sellers of ships, shipowners, and operators, as well as the owners of goods and operators. The number of intermediary companies increased rapidly during the First World War as they established themselves as a major institution in the shipping world. For example, the number of members of the Kobe Shipping Industry Union, which was made up of 
many intermediary companies, greatly increased during the First World War, from 32 companies in 1916 to 111 in 1918 and 116 in 1920. While the relatively small amount of capital required to open an intermediary company meant that the rate of turnover was high, many of the companies operating during the war had begun operating during the Meiji period.

Let us now turn to some examples of how shipowners and charterers were connected by intermediary companies within the shipping market. In the case of Inui GMK, which operated most of its ships for hire, the statements of people involved with the company during this period have revealed that the charter-oriented shipowner was connected to the market through a specific intermediary company, in this case Yamamoto, Inc., led by Yamamoto Otogorō. However, this method of connecting to the market, which relied on close, personal relationships, at times led to problems, as seen in the following case, in which the Kobe Shipping Industry Union reprimanded one of its members.

In this case, Suzuki Inc. sought to charter Nagata Sanjūrō's steamship, Shigaura Maru, through its chartering agent, Seiwa, Inc., an intermediary company. Seiwa and Nagata reached an agreement in their chartering negotiation, which was mediated by another intermediary firm, Oguri GMK. Shortly after this, however, Hikabe GMK, a competing company, contacted Seiwa to suggest that they could negotiate a more favourable outcome than that reached with Oguri, given the special relationship between Hikabe and Nagata. Once Seiwa switched from Oguri to Hikabe, however, Nagata refused to agree to a contract as long as the charterer was Suzuki.

In cases like this, shipowners and charterers were connected by specific intermediaries, like Yamamoto for Inui and Hikabe for Nagata. As a result, the choice of shipowner from whom one chartered was heavily dependent on the intermediary's information network. In the most concrete terms, the shipping market was embodied by the connections between the charterers and shipowners that were established through the intermediaries.

The limitations of these personal networks, however, seem to have been supplemented by the geographic proximity of the intermediaries as well as the shipowners. For example, a contemporary document explains the concentration of shipowners in Kobe in the following way: 
The port of Kobe is the central freight rate market in Japan as well as in the Orient. All shipowners in Japan have either established an office or at least have an agent there. Major intermediaries in Kobe maintain connection with freight rate markets throughout Japan as well as overseas, enabling them to rapidly receive information on changes in global freight rates, demands for cargo space, and supplies of cargo. ${ }^{16}$

In other words, it was becoming general practice for both new and existing shipowners to have a base of operation in Kobe. In fact, many of the shipowners active during this period were concentrated in Kobe, including Mitsui Bussan's shipping department (Kaigan-dōri), Yamashita Steamship (Sakae-chō), Uchida Steamship (Nakamachi), and Katsuda Steamship (Nakamachi).

The geographic proximity of the shipping brokers was even more conspicuous than that of the shipowners. For example, of the 116 companies in the Kobe Shipping Industry Union in 1920, a total of 70 (accounting for $60 \%$ of the union members) had bases in Kobe, including 31 along the Kaigan-dōri in the former foreign settlement and 39 in Sakae-chō. There is the possibility, then, that limits to personal networks were supplemented by the geographic proximity of these companies.

In fact, a contemporary document comments on the efficiency of the network of intermediaries, as follows:

Because Kobe is the center of Japanese shipping, news from around Japan concerning freight rate contracts, time charter, buying and selling, disaster at sea, and conflicts spreads within a day among those in the business in Kobe, while their counterparts in Osaka and Kobe receive the same news a half day or a day later. Market conditions are not only reported by the ten-day and monthly reports of the Kobe Shipping Exchange but also by several Kobe dailies specializing in the industry, who compete with each other in rapid reporting.

16. Susumu Takano, Senpakugyō no keiei [Managing a shipping company] (Tokyo: Bungadō, 1926), 215. 




In other words, the concentration of firms in Kobe not only led to the concentration of shipping-related news from throughout Japan in the city but also enabled the extremely rapid transmission of information among industry members through trade papers and other media. The rise of a large number of charter-oriented shipowners, the diversification of the major charterers, and the emergence of intermediary companies, which facilitated efficient searches for trading partners, transformed the shipping market into an increasingly generalized system that was open to parties other than Mitsui Bussan.

Thus, while the formal institution of an exchange, as envisioned for the Kobe Shipping Exchange, was not established in the end, a system for the coordination of trade did exist. In Japan, the transformation of the shipping industry during the First World War produced an unofficial system in which geographically proximate intermediaries connected the owners of goods, charterers, and charter-oriented shipowners through their own personal networks. As a result, even when an official shipping exchange was created, it could not fully function. Not only that, the existence of this unofficial system served as the foundation for the expanding international activity of Japanese trading companies during this period.

\section{Transformation into a Fixed Exchange System: the Interwar Period $^{17}$}

The interwar period witnessed a striking rise in international activity among Japanese shipowners, which in turn enabled Japanese trading companies to gain international competitiveness in cooperation with the shipowners. In order to illuminate this point, let us turn to the major trends in the shipping market of this period. We have already noted how, after the First World War, Japan possessed the third-largest shipping industry in the world, which put the port of Kobe in competition with London to the extent that developments in the latter immediately affected freight rates in the former. However, the need for the existence

17. On interwar shipping markets, see: Hisayuki Ōshima, "Ryō-taisenkanki ni okeru kaiun shijō no henyō to mitsui bussan yusō gyōmu" [The relationship between changes in shipping markets and Mitsui Bussan's shipping business], Keieishigaku, 43.4 (2009): 3-27. 

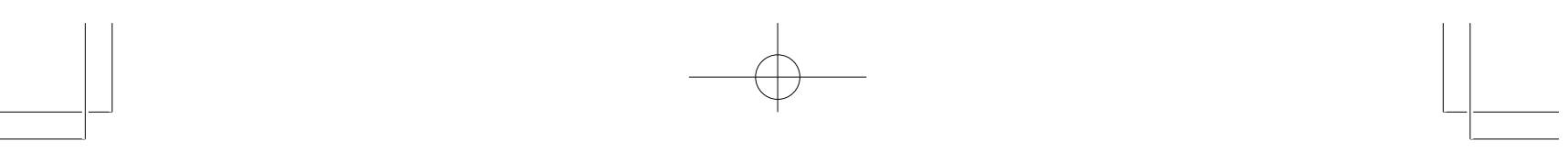

98

JAPANESE RESEARCH IN BUSINESS HISTORY 2011 | 28

of the intermediary companies, who were the primary agents in the chartering market into the beginning of the Shōwa period (1926-1989), gradually weakened. The main cause of this trend was the transformation of an increasing number of trampers into liners in sealanes from the last half of the 1920s into the 1930s.

The transformation of trampers into liners was, in fact, a global phenomenon. This was due to factors such as the relative increase in shipments of small, semi-finished and finished goods in contrast to the decrease in bulk shipments of raw materials as a result of industrialisation, as well as improvements made in port and storage facilities, facilitating food transport and the consequent accelerated loading of goods. This resulted in the global decline of chartering markets, which had brought the owners of goods and of trampers together. In the case of Britain, the number of trampers and of liners were at parity before the First World War, but the share of trampers in the industry had decreased to around $30 \%$ by the first half of the 1930s. As a result, the growing number of dealings that did not need to go through the Baltic Exchange lowered the significance of the City of London's function in shipping.

Amidst this global stagnation of chartering markets and transformation of trampers into liners, the latter process among the Japanese shipowners had one major distinguishing feature. It has already been noted that a large number of ships were imported into the Japanese market during the First World War, but this trend continued on during the interwar period as used ships were imported to the extent that Japan had seemingly become a graveyard for old vessels. In order to gain new markets for these ships, major shipowners managed to increase their number of cargo collections and vessel assignments by acting essentially as trampers, going as far as actively loading bulk freight suitable for trampers. ${ }^{18}$ For example, Yamashita Steamship expanded its activity by actively pursuing berth business, in which the company accepted tramper cargoes that were customarily fully loaded into ships in small lots, which were then combined and treated in the same manner as cargoes in liners in terms of setting the conditions for loading and unloading. With formerly tramper-oriented cargoes being

18. Nakagawa, 16, 160.
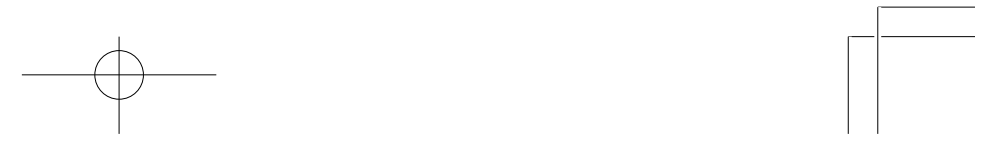
increasingly transported by liner, dealings with liner companies gained greater importance than the traditional chartering markets in trading companies' transportation arrangements.

At the same time, Japanese shipowners were greatly increasing their influence in the Pacific line, which occupied an important place in international trade. While this period witnessed the growth of Pacific trade as well as that of direct routes via Panama, the share of the trade between the United States and East Asia handled by American and British ships decreased rapidly throughout the 1930s. Prior to 1930, American and British ships had each loaded a third of the cargo transported on this line, while the remaining third was shared by Japanese and other vessels. By 1938, the Anglo-American share decreased to $11 \%$ for the U.S and $16 \%$ for the UK, while much of the expanding cargo on this line was transported by Japanese shipowners.

Another point worth noting in the expansion of Japanese shipping firms during this period is the fact that their growth was founded on the expansion of Japanese trade as a whole. The shipping industry had been a free industry primarily based on the global market and, as such, the expansion of a given country's trade was never directly correlated to the development of that country's shipping industry (unless the government pursued a policy that heavily promoted domestic ships). During this period, however, the growth of Japanese trade was, in fact, directly connected to that of Japanese shipping. In the United States, in contrast, the percentage of foreign trade goods that were loaded by American ships had traditionally remained low since the last half of the nineteenth century, amounting to $14 \%$ in 1910 and $19 \%$ in 1915, but rising to $51 \%$ in 1920 , due to mass wartime construction of ships. However, this percentage declined in a conspicuous and sustained manner in the postwar period, going down to $38 \%$ in $1925,37 \%$ in $1930,35 \%$ in 1935 , and $25 \%$ in 1939. During the same period, the ratio of Japanese ships to Japanese country's trade rose rapidly, from 50\% in 1913 to $75 \%$ in 1923 and remained at an extremely high level in subsequent years, amounting to $69 \%$ in $1925,70 \%$ in 1929 , and $66 \%$ in $1935 .{ }^{19}$

At the basis of this expansion of Japanese trade and the high share

19. Nakagawa, 28-29, 243-44.
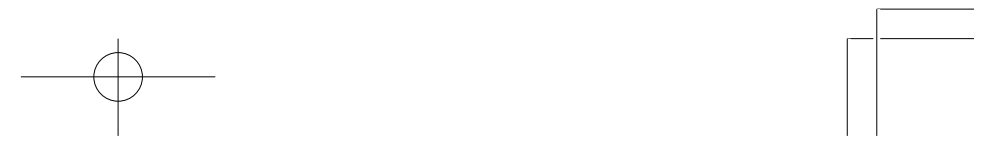
maintained in it by Japanese shipping was the cooperation between shipowners and the Japanese trading companies. During this period, Japanese shipowners and trading companies solidified their dealings by the widespread use of secret rebate agreements.

In regular lines, it was typically impossible for a particular owner of goods to receive preferential treatment, since a shipping conference would be formed to regulate freight rates, etc. However, because Japanese trading companies maintained strong connections to shipowners, they were treated favourably in determining freight rates. Since these secret freight rebate agreements happened behind the scenes, they were different from the more public deferred rebate system, which was widely used on regular lines with the assumption of a permanent business relationship. ${ }^{20}$

For example, the Seattle branch of Mitsui Bussan had for some time succeeded in selling wheat flour, the main commodity in which it traded, to Dalian and Tianjin largely due to the extremely low freight rate it secured from the shipping company. The establishment of a shipping convention in its sea-lane, however, meant that Mitsui would lose the preferential treatment that was at the basis of its business. Because of this, the Seattle branch made a secret agreement with Kawasaki Steamship Co., securing a discounted freight rate. In order to prevent the violation of the convention from becoming public knowledge, the actual nature of the contract was only known by the manager of the wheat trade and the financial officer. The rebate was collected on a monthly basis and paid in the form of a personal remittance bill, which was then inserted into the branch's account and labelled as a share from the profits made in the wheat trade. Special rebate agreements of this sort were also made by Mitsui's branches in New York and Sydney, and special care was taken to keep them secret as well. ${ }^{21}$

20. On the rebate system within the conference system, see Sturmey, 322-343.

21 . These rebate practices were examined through the analysis of documents that were seized by the Allied forces during the occupation of Japan and stored at the U.S. National Archives and the National Archives of Australia. For further details, see Ōshima, "Ryō-taisenkanki ni okeru kaiun shijō no henyō to Mitsui Bussan yusō gyōmu" [The relationship between changes in shipping markets and Mitsui Bussan's shipping business].
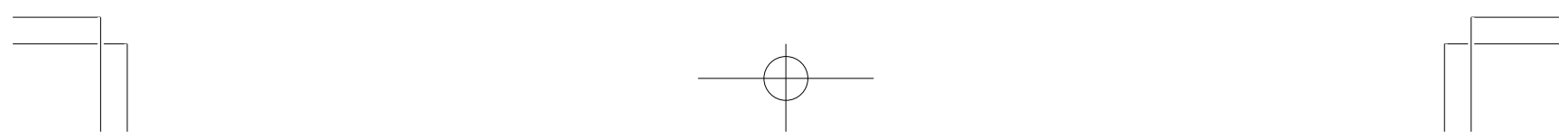
In 1930, Mitsui Bussan as a whole made a special agreement with Osaka Shōsen Kaisha (OSK Lines), stipulating that OSK would pay a $5 \%$ rebate to Mitsui on its foreign lines. The agreement also provided for an additional $10 \%$ rebate if this was deemed necessary in order to secure a transaction and was accompanied by an explanation from Mitsui. Naturally, the agreement was kept secret from the managers in charge of accounting, sales, and delivery, and was only known at Mitsui by the department manager and his representative. Through this agreement, OSK in 1931 replaced Nippon Yūsen Kaisha in its long-held position as Mitsui's largest business partner. In fact, Nippon Yūsen very likely established a similar relationship with Mitsubishi Trading Company during the same period.

In this way, Japanese trading companies used their special relationships with the increasingly powerful shipping firms to gain a powerful competitive edge in international trade.

\section{Conclusion}

This essay has examined how a system that facilitated efficient transportation trade between trading and shipping companies emerged in Japan, in connection with the formation of the modern Japanese shipping market. This process can be summarized as follows:

During the 1900s, the absence of a shipping market necessitated an organized response from trading companies that had transportation needs but faced difficulty in chartering ships efficiently. This essay examined the cases of Mitsui Bussan and Mitsubishi GSK as examples. In the case of Mitsui, which dealt with a variety of commodities across a large geographic area, the company formed an internal organisation to coordinate the demand for cargo space that emerged within the company in an efficient manner. In contrast, Mitsubishi, which dealt with a limited type of commodity within a limited area, sought to correct the imbalance arising between round-trip cargoes by entering into a long-term contract to transport Daye iron ores as the return cargo. During this period, maritime transportation deals were often coordinated by Mitsui, the preeminent trading company. As a result, some shipping companies involved in the trade found themselves to be at a disadvantage.
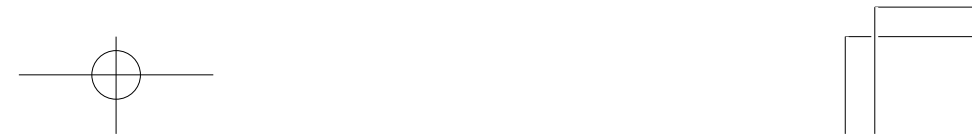
However, the unprecedented boom experienced by both shipping and trading companies in Japan during the last half of the 1910s transformed the circumstances surrounding the shipping industry. While this period witnessed a massive increase in the number of charter-oriented shipowners, it also saw the rise of major charterers whose offices were concentrated geographically close to the former foreign settlement in Kobe. Combined with the growth of intermediaries, who brought all the parties involved in the transport trade together, this made Kobe a shipping market of global stature in the Far East. As a result, the coordination of transport demands, which in the late Meiji period had been largely conducted internally by trading companies, now moved to the marketplace. The formation of a market in transport deals involving trading companies served as an important element enabling the international activities of the numerous trading companies that were established during this period.

This essay also examined the international competitiveness of Japanese trading companies as well as the shipping industry from the perspective of the transport trade, as follows. The 1920s witnessed a major decline in the function of charter markets. During this period, an increasing number of trampers were transformed into liners around the world. At the same time, there was a decline in the position of the British shipping industry, whose high competitiveness had been based in part on the existence in London of the Baltic Exchange, a shipping exchange of global stature. In contrast, the international competitiveness of the Japanese shipping industry grew during the same period. The same was true for Japanese trading companies, which strengthened their international competitiveness in the interwar period, while their British counterparts struggled with unprofitable operations. The source of the competitiveness of Japanese trading and shipping companies lay in their cooperation with one another based on long-term, fixed business relationships that included secret rebate contracts. As a result, the power of Japanese trading and shipping companies expanded greatly in the Pacific line, which occupied a key position in international trade throughout the 1930s.
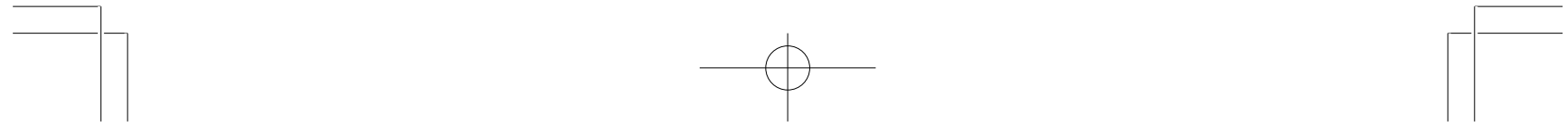


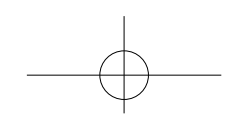

\section{Bibliography}

Chida, Tomohei. Kaiun shijōron [On shipping markets]. Tokyo: Yūhikaku Publishing Co., Ltd, 1958.

Imperial Shipping Committee. British Shipping in the Orient. 1938. (Osaka Shōsen, trans. Tōyo ni okeru eikoku kaiun [British shipping in the orient]. 1939: 123-129)

Jones, Geoffrey. Merchants to Multinationals: British Trading Companies in the Nineteenth and Twentieth Centuries. Oxford: Oxford University Press, 2000.

Kasuya, Makoto. Gōshō no meiji [Meiji of the wealthy merchants]. Aichi: The University of Nagoya Press, 2002.

Nakagawa, Keiichirō. Ryō-taisenkan no nihon kaiungyō [Japanese shipping industry in the interwar period]. Tokyo: Nihon Keizai Shinbunsha, 1980.

-. Ryō-taisenkan no nihon kaiungȳ̄-sono keieishiteki kōsatsu [Japanese shipping industry in the interwar period-its analysis from the perspective of business history]. Tokyo: Chuo University Press, 1985.

Nihon kaiun shükaijo nijūnenshi [Twenty-year history of the Japan Shipping Exchange]. 1941.

Nihon kaiun shūkaijo sōritsu gojūnenshi shōshi [A short history on the 50th anniversary of the opening of the Japan Shipping Exchange]. 1972.

Ōshima, Hisayuki. "Dai ichiji taisenki ni okeru yōsen shijō" [Chartering markets during the First World War]. Takachiho ronsō, 35.4 (2001).

-. "Kan'ei yahata seitetsujo ni okeru kōseki yusō" [Iron ore transportation in the staterun Yahata Steelworks], Enerugīshi kenkyu, 19 (2004).

-. "Mitsui bussan ni okeru yusō gyōmu to yōsen shijō" [Mitsui Bussan's transport business and the chartering market]. In Nakamura Satoshi and Nakamura Naofumi, eds, Shōhin ryūtsū no kindaishi [A modern history of commodity circulation]. Tokyo: Nihon Keizai Hyōronsha, 2003.

-. "Ryō-taisenkanki ni okeru kaiun shijōno henyō to mitsui bussan yusō gyōmu" [The relationship between changes in shipping markets and Mitsui Bussan's shipping business]. Keieishigaku, 43.4 (2009).

Segawa, Shizuo. Kaiun kōkokushi [History of the rise of a shipping nation]. Osaka: Kaiji Ihōsha, 1927.

Sturmey, S. G. British Shipping and World Competition. London: University of London, Athlone Press, 1962.

Takano, Susumu. Senpakugyō no keiei [Managing a shipping company]. Tokyo: Bungadō, 1926.

Thornton, R.H. British Shipping. Cambridge: Cambridge University Press, 1939.

Keywords: Japanese shipping, Trading company, Interwar period, Mitsui, Mitsubishi 